\title{
鼠䖯の季節的消長
}

\section{Seasonal prevalence of rodent fleas}

\section{中沢浩三* 大石 勇* 久米淸治* \\ Kozo Nakazawa, Isamu Oisi and Seiji Kume}

\section{I. 緒 言}

蚛は周知の如く人に伝染病を媒介するのみならず，其 刺咬に依り人畜の受ける被害は甚しいものがある，従て 之を防除する為には其の種類, 分布, 季節的消長等を調

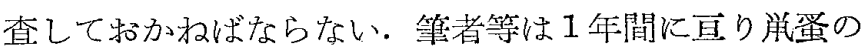
季節的消長を調へ，其結果を得たのでこつに報告する.

\section{II. 調查方法}

1955 年 3 月上り 1956 年 2 月迄 1 年間比亘り本学㩐内 (都下府中市) 江於て其月の上,下旬の 2 回夫々各回 10 個 の金網籠を用いて(月の延籠数は 20 個) 捕絾を行つた。

捕獲せる単梳クロ、ホルムにて殺し, 俩主体を離れた
の $-8.0^{\circ} \mathrm{C}$ であつた.

\section{III. 調 查 成 綪}

本期間に採集せる単恃 Rattus rattus, Rattus norvegicus の 1 属 2 種にして総数は 107 匹，其内訳は前者が 64 匹，59.8\%，後者は 43 匹，40.2\%でめつた。

第 2 表炕示す如く Rattus norvegicus は其捕獲場所子 偏在して和り，捕獲数子少く且. Rattus rattus と生活環 境を異にするので今回は除外し Rattus rattus の寄生蛋 に就き調べた。

採集崔る蛍は第 3 表に示す如く総数は 201 匹で之を種 類別に見ると，Nosopsyllus fasciatus 125 匹，62.1\%， Monopsyllus anisus 19 匹, 9.4\%, Leptopsylla segnis 57

第 1 表 月別年間糹温（1955. III 1956. II 於東京農工大学農学部農場観測)

\begin{tabular}{c|c|c|c|c|c|c|c|c|c|c|c|c}
\hline 月 & III & IV & V & VI & VII & VIII & IX & X & XI & XII & I & II \\
\hline $\mathrm{T}^{\circ} \mathrm{C}$ & 8.1 & 13.5 & 18.2 & 22.8 & 27.4 & 26.2 & 21.9 & 17.6 & 10.3 & 6.6 & 3.3 & 3.4
\end{tabular}

第 2 表捕鼠実施場所飞捕鼠数

\begin{tabular}{|c|c|c|c|c|c|c|c|c|c|c|c|c|}
\hline 種 名 & $\begin{array}{c}\text { 捕鼠実施 } \\
\text { 場 } \\
\text { 捕鼠数 }\end{array}$ & $\mid \begin{array}{l}\text { 内科 } \\
\text { 学生実習 } \\
\text { 窒 }\end{array}$ & $\begin{array}{l}\text { 家畜病 } \\
\text { 院馬房 }\end{array}$ & $\begin{array}{l}\text { 家畜病院 } \\
\text { 入院犬等 }\end{array}$ & 学生寮 & $\begin{array}{l}\text { 職員 } \\
\text { 食堂 }\end{array}$ & $\begin{array}{l}\text { 農場 } \\
\text { 鵴舎 }\end{array}$ & $\begin{array}{l}\text { 農場 } \\
\text { 豚舍 }\end{array}$ & \begin{tabular}{|l|}
$\mid$ \\
農場 \\
山羍舎
\end{tabular} & 農場 & 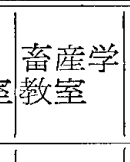 & 計 \\
\hline $\begin{array}{l}\text { Rattus } \\
\text { rattus }\end{array}$ & No. & 8 & 7 & 8 & 8 & 3 & 14 & 8 & 4 & 2 & 2 & 64 \\
\hline $\begin{array}{l}\text { Rattus } \\
\text { norvegicus }\end{array}$ & No. & 4 & $\gamma$ & $\gamma$ & I & 35 & $\zeta$ & I & I & 4 & $\zeta$ & 43 \\
\hline
\end{tabular}

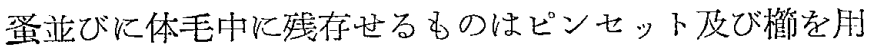

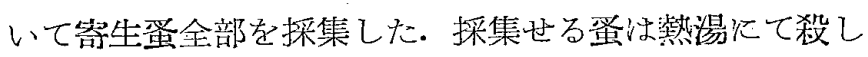
た後，10\%苛性ソーダ液に一昼夜大れ，其後 70\%，90\% 脱水アルコール，カルボール・キシロールル䐓次 5 分宛 䢜した後バルサムにて封大して同定を行つた。

気温は本学農場にて観測せるものにして（中央気象台 の依頼に低て行つてる), 测定は毎日午前 9 時に行つて居 る. 各月平均気温は第 1 表の如くで本期間中の最高気温 は 7 月下旬, 8 月上旬の $33.7^{\circ} \mathrm{C}$, 最低気温は 1 月下旬

* 東京農工大学農学部獸医学科

Division of Veterinary Medicine, Faculty of Agriculture, Tokyo University of Agriculture \& Technology
匹，28.3\%，の3 属 3 種で Nosopsyllus fasciatus が最も 多かつた. 又上記 3 種の他倍科火寄生すると謂われる 他の 種類即ち Xenopsylla cheopis, Paradoxopsyllus curvispinus, Echidnophaga gallinacea, Tunga caecigea は寄生して居なかつた。少大舎内で捕雀せるものに 8 月 唯一度 1 匹目の Ctenocephalides felis 古学採集したが山後 一度もC. canis む C. felis も採集されなかつた。 各種類別に季節的消長を其蛋指数（採集蛋数 $\div$ 捕獲觉 数, 以下f. i. と略す)に依て見ると, Nosopsyllus fasciatzos の場合は第 1 図に示与如く f.i. は 4 月上り漸次增加し 5 月で最大となり其年の最高の指数を示す. 其後は次第 に減少し f. i. は1 以下となり夏期には殆ど見られなく なるが秋沉大るに良い逐次増加し 11 月に再び山が見ら 
第 3 表 Rattus rattus 寄生蛋採集成績

\begin{tabular}{|c|c|c|c|c|c|c|c|c|c|c|c|}
\hline \multirow{2}{*}{ 月 } & \multicolumn{2}{|l|}{ 榆 } & 鼠 & \multicolumn{2}{|c|}{ 検 出 } & \multicolumn{2}{|c|}{$\begin{array}{l}\text { Nosopsyllus } \\
\text { fasciatus }\end{array}$} & \multicolumn{2}{|c|}{$\begin{array}{l}\text { Monopsyllus } \\
\text { anisus }\end{array}$} & \multicolumn{2}{|c|}{$\begin{array}{l}\text { Leptopsylla } \\
\text { segnis }\end{array}$} \\
\hline & $\begin{array}{l}\text { 捕 獲 } \\
\text { 鼠総数 }\end{array}$ & $\begin{array}{l}\text { 鼬保有 } \\
\text { 数 }\end{array}$ & 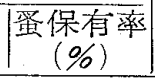 & $\begin{array}{l}\text { 䌊総数 } \\
\end{array}$ & 蛋指数 & 蛋 数 & 蛋指数 & 蛋 数 & 蛋指数 & 掻 数 & 蝈指数 \\
\hline 3 & 6 & 5 & 83.3 & 7 & 1.2 & 4 & 0.7 & 3 & 0.5 & 0 & 0 \\
\hline 4 & 8 & 7 & 87.5 & 19 & 2.1 & 12 & 1.5 & 1 & 0.1 & 6 & 0.8 \\
\hline 5 & 6 & 6 & 100 & 74 & 15.7 & 33 & 5.5 & 6 & 1.0 & 35 & 5.8 \\
\hline 6 & 6 & 5 & 83.3 & 15 & 2.5 & 10 & 1.7 & 2 & 0.3 & 3 & 0.5 \\
\hline 7 & 3 & 0 & 0 & 0 & 0 & 0 & 0 & 0 & 0 & 0 & 0 \\
\hline 8 & 2 & 1 & 50 & 1 & 0.5 & 1 & 0.5 & 0 & 0 & 0 & 0 \\
\hline 9 & 3 & 0 & 0 & 0 & 0 & 0 & 0 & 0 & 0 & 0 & 0 \\
\hline 10 & 6 & 3 & 50 & 4 & 0.7 & 2 & 0.3 & 0 & 0 & 2 & 0.3 \\
\hline 11 & 5 & 2 & 40 & 13 & 2.6 & 3 & 0.6 & 1 & 0.2 & 9 & 1.8 \\
\hline 12 & 6 & 1 & 16.6 & 1 & 0.2 & 1 & 0.2 & 0 & 0 & 0 & 0 \\
\hline 1 & 7 & 3 & 42.8 & 34 & 4.9 & 27 & 3.9 & 5 & 0.7 & 2 & 0.3 \\
\hline 2 & 6 & 4 & 66.6 & 33 & 5.5 & 32 & 5.3 & 1 & 0.2 & 0 & 0 \\
\hline
\end{tabular}

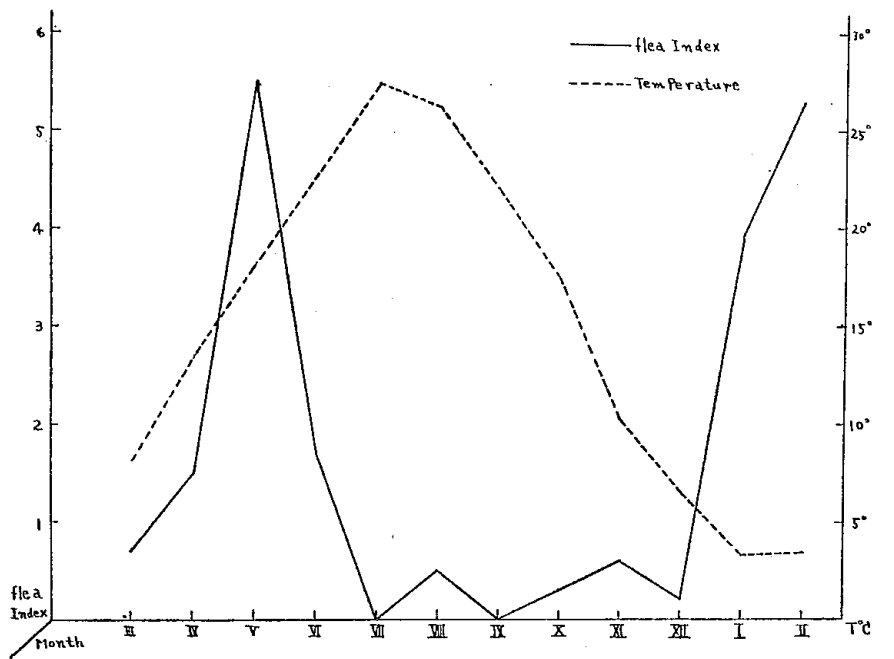

筑 1 図 Nosopsyllus fasciatus の季節的消長 Fig. 1 Saesonal prevalence of Nosopsyllus fasciatzs

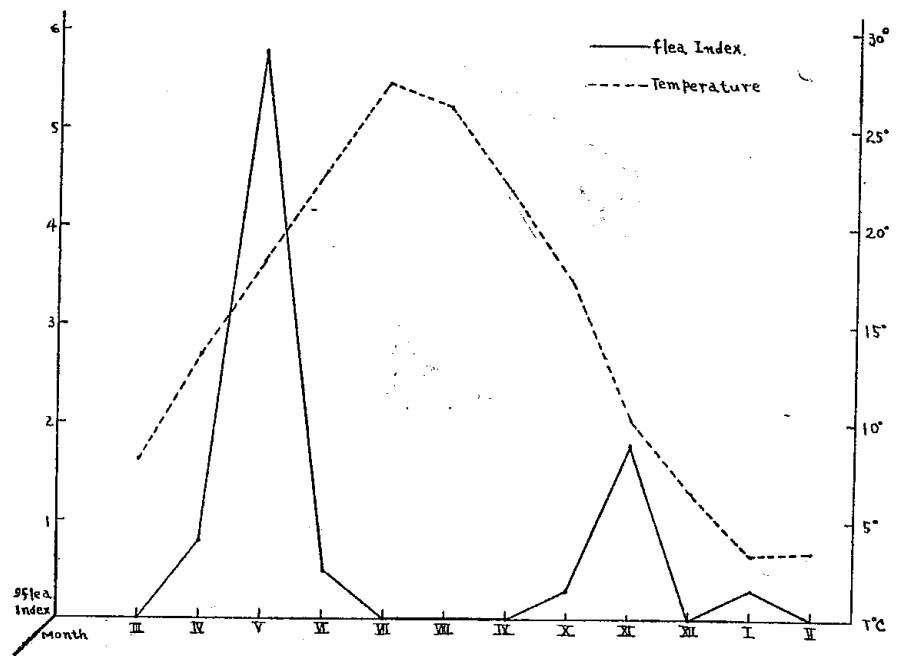

第 3 図 Leptopsylla segnis の季節的消長

Fig. 3 Seasonal prevalence of Leptopsylla segnis

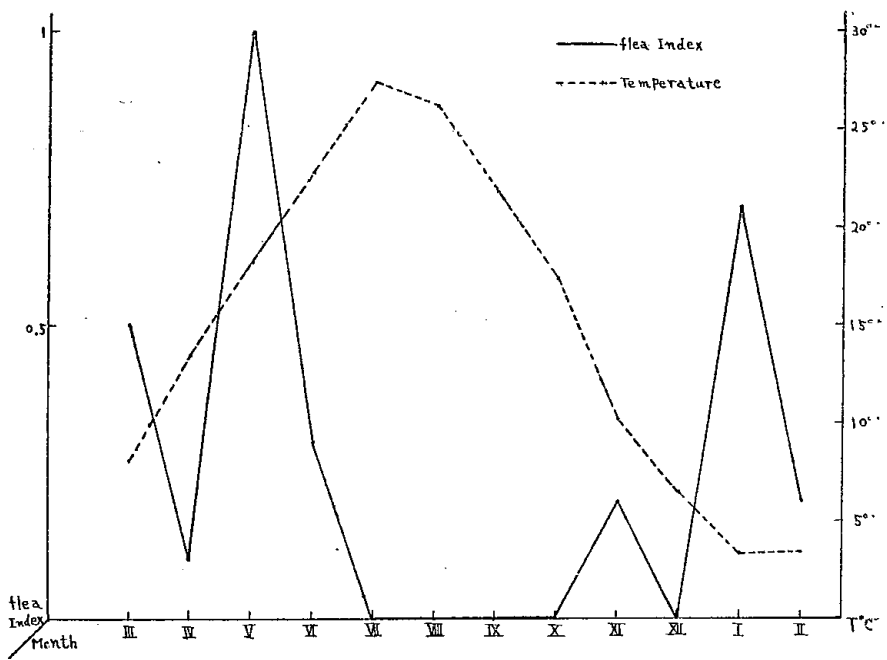

第2図 Monopsyllus anisus の季節的消長

Fig. 2 Seasonal prevalence of Monopsyllus anisus

れる. 一方冬期には，1，2 月に可成増加して居る様 である.

Monopsyllus anisus, Leptopsylla segnis の場合は 第 2 区，第 3 困の如く何れも 5 月に大きな山を有し 且それが其年で最高の指数であることは前者々同様 である.7月以降夏期には全く見られず，秋に至り 次第に見出される様になり 11 月に山を描いて居る， 倘冬期には余り見出されないが 1 月に小さな山を有 する。

指数と気温との関係は気温が漸次上冢するに従て f. i. の堌加が見られるが，気温が $20^{\circ} \mathrm{C}$ 以上にな ると逆に f. i. 屽減少する様に見られる。

併し冬期には気温の低下にもか〉わらず f. i. は 一般に堌加して居るが何分にも1回の調查であり， 


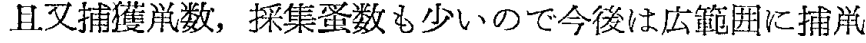
定行い，且それと平行して蛋の飼育をも行つてみる積り でる。

\section{IV. 総 舕}

1955 年 3 月より 1956 年 2 月に至る 1 年閒に亘り本学

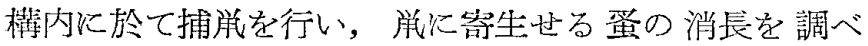
た.

捕隻せる䋃は Rattus rattus 64 匹几，Rattus norvegicus 43 迄の 1 属 2 種であつた.

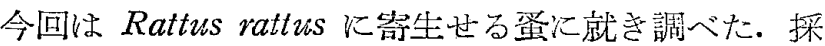
集せる登は

Nosopsyllus fasciatus 125 匹, 62.1\%. Monopsyllus anisus 19 匹, 9.4\%. Leptopsylla segnis 57 匹, 28.3\% の総計 201 记で Nosopsyllus fasciatus が最も多かつた。 他の毟奇生性の虫即ち Xenopsylla cheopis, Paradoxopsyllus curvispinus, Echidnophaga gallinacea, Tunga caecigea は1匹も採集されなかつた。

季節的消長では，何れの種類も5月に其年の中で最大 の指数を示した.

7 月以降夏期には殆ど見られず，10月以隆より多少出 現し11月に川党描いて㢄た。

攸冬期にも増加が見られた。

気蕰との関係は $10^{\circ} \sim 20^{\circ} \mathrm{C}$ で増加し， $20^{\circ} \mathrm{C}$ 以上で は逆に減少する樣に見られた。

\section{交献}

1) 青木文一郎 (1931)：哺乳類. 岩波講座生物学. 一 2) 佐々学 (1946)：鼠の衞生学的検查法. 公臬瑺生 学雑誌，4 (1)，- -3) 传々学 (1950)：鼠の習性の生 態. 公瞅衞生学雑誌，7 (5). - 4) 佐々学 (1948):
ねずみ（1）（11）。自然， $3(10) ，(11) ，-5)$ 佐々 学: 疾病已動物。岩波全書. 一6) 権国権三郎 (1950): ねずみのとり方. 公衆衞生学雑誌, $7(5)$. 一7) 德 永雅明 (1943)：医用昆虫学 (下). 診療々経験社。一 8) 三坂和英 (1953)：野鼠とその防除。日本学術振 興会. - 9) 長谷川恩 $(1947)$ ：柇幌市に於て佳家性 鼠上り検出せる翼類に就て。松虫， $2(2) .-10)$

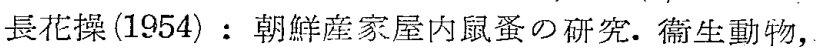
4, 特別号. 一11) 八曰享二(1944)：新潟市及其近 郊産ぞぶねずみの鼠掻に就て。医学々生物学, 6(5). -12) Ryckman, R. E. et al. (1954) : Seasonal Incidence of Fleas of the California ground squirrel in Orange County, California, Jour. Eco. Ent. 47 (6).

\section{Summary}

The seasonal prevalence of fleas on Rattus rattus were studied at Fuchu, Tokyo, through consecutive 12 months, from March, 1955, to Feburuary, 1956.

The fleas were Nosopsyllus fasciatus, Monopsyllus anisus and Leptopsylla segnis.

Xenopsylla cheopis, Paradoxopsyllws curvispinus, Echidnophaga gallinacea and Tunga caecigea were not found during this survey.

All the three species showed their top peal: of prevalence in May 1955.

The fleas are quite seldom during the summer season but after October the flea index gradually increases and showed a second peak in November. Therefore it seems that under the airtemperature between $10^{\circ} \mathrm{C}$ and $20^{\circ} \mathrm{C}$ the fleas may increase and decrease if the temperature ascend above $20^{\circ} \mathrm{C}$. 